\title{
Ribosomal Protein S27-Like is overexpressed in glioma cells and inhibition of RPS27L expression suspends the tumorigenesis
}

Primary research

Keywords:

Posted Date: December 14th, 2020

DOl: https://doi.org/10.21203/rs.3.rs-49193/v3

License: (c) (i) This work is licensed under a Creative Commons Attribution 4.0 International License.

Read Full License 


\section{Abstract}

The authors have requested that this preprint be withdrawn due to author disagreement.

\section{Full Text}

The authors have withdrawn this preprint from Research Square. 